\title{
Effect of Osmotic Stress on the Organic Acid Production Profile and Tricalcium Phosphate Solubilization by Osmotolerant Bacteria
}

\author{
Gurupadam Hema Bindu $^{1}$, Govindan Selvakumar ${ }^{1 *}$, Kaushal K. Upreti ${ }^{1}$, \\ Narayana Sunil Kumar ${ }^{2}$ and Duraisamy Kalaivanan ${ }^{1}$ \\ ${ }^{1}$ ICAR-Indian Institute of Horticultural Research, Hesaraghatta Lake Post \\ Bengaluru-560089, India \\ ${ }^{2}$ Gokaraju Rangaraju Institute of Engineering and Technology, Hyderabad, India
}

*Corresponding author

\section{A B S T R A C T}

Keywords

Osmotolerant,

Organic acids,

Phosphate

solubilization

Rhizobacteria

Article Info

Accepted:

10 November 2018

Available Online:

10 December 2018
Osmotolerant Plant Growth Promoting Rhizobacteria (PGPR) plays an important role in plant growth promotion in water stressed environments. Since phosphate solubilisation is one of the major mechanisms of plant growth promotion under water stressed conditions, this study was conducted to determine the effect of osmotic stress on the organic acid production profile and phosphate solubilization abilities of twelve osmotolerant bacterial isolates in NBRIP medium supplemented with 25\% PEG 8000 (-1.97 MPa). It was observed that the imposed level of osmotic stress did not significantly affect the production of citric, formic, 2-keto glutaric, lactic, malic, malonic propionic and tartaric acids. Most isolates were able to solubilize tricalcium phosphate more efficiently under in vitro osmotic stress conditions compared to normal conditions. The soluble P released from tri calcium phosphate by the isolates ranged from 2.78-25.22 ppm under non osmotic conditions, while it ranged from 4.67-53.56 ppm under osmotic stress conditions. Amongst the osmotolerant bacterial cultures, Bacillus amyloliquefaciens P-72 recorded significantly higher soluble $\mathrm{P}$ concentrations $(53.56 \mathrm{ppm})$ under osmotic stress conditions while the isolate Enterobacter sp. P-39 recorded the lowest soluble P concentration (4.98 ppm).

\section{Introduction}

Phosphorus is an essential element which is a component of DNA, RNA, ATP, ADP and phospholipids of all living organisms. It is a major plant nutrient essential for growth and development of plants besides being involved in important metabolic pathways like photosynthesis, biological oxidation, nutrient uptake and cell division (Illmer et al., 1992).
Phosphorus deficiency limits crop production and causes a reduction in the nutritional quality of the plant produce. The phosphate reserves in the soil are mostly in the insoluble forms and are not available to plants. Insoluble phosphate compounds in the soil can be solubilized by organic acids produced by plants and microorganisms (Duponnis et al., 2005; Kucey, 1983). Application of phosphate solubilizing rhizobacteria increases soil 
fertility due to their ability to convert insoluble $\mathrm{P}$ to soluble $\mathrm{P}$ by releasing organic acids, chelation and ion exchange (Whitelaw, 2000; Narula et al., 2000; Omar, 1998). It is generally accepted that the major mechanism of the mineral phosphate solubilisation is the action of organic acids synthesized by bacteria. Organic acids that solubilise phosphates are mainly citric, lactic, 2-ketoglutaric, oxalic, tartaric and acetic acids (Vazquez et al., 2000; Kucey, 1983). These organic acids are able to dissolve the mineral phosphates and make them available for the plant uptake (Bhattacharya and Jain, 2000). But the organic acid profile and the levels of individual organic acids differ amongst microbes and are greatly influenced by the edaphic conditions such as soil moisture. Soil moisture deficit stress is a crucial factor that influences the growth and functionality of both plants and rhizospheric microbes. Under water stressed situations the enhancement of phosphorus availability in the root zone is crucial for root development and subsequent water and nutrient uptake. This can be enhanced by the application of osmotolerant rhizobacterial strains that retain their functionality under water deficit conditions (Selvakumar et al., 2013). Therefore, an attempt was made to study the effect of osmotic stress on the organic acid production profile and the phosphate solubilization potential of osmotolerant bacteria under in vitro conditions.

\section{Materials and Methods}

\section{Bacterial isolates}

The bacterial isolates used in this study viz., Bacillus amyloliquefaciens P72, Pseudomonas sp. CP3, Bacillus spp. CP2, G4, R7, Enterobacter spp. P39, P41, P46, P68, P76 and the Actinobacterial isolate Citricococcus zhaciaensis B-4, were originally isolated from the rhizospheres of different crops grown in arid conditions on PEG 8000/mannitol supplemented nutrient agar at osmotic potentials ranging from -2.1 to $-2.92 \mathrm{MPa}$. Isolates were subsequently identified by the sequencing of the $16 \mathrm{~S}$ rRNA gene and determination of their percent identities with the NCBI database through a BLASTn search.

Determination of the organic acid profile in the culture supernatant by HPLC and soluble $P$ concentrations by spectrophotometry

For the quantification of organic acids, NBRIP (National Botanical Research Institute's Phosphate) medium containing $10 \mathrm{~g}$ glucose, $1 \mathrm{~g}$ of $\mathrm{Ca}_{3}\left(\mathrm{PO}_{4}\right)_{2}, \mathrm{MgCl}_{2} .6 \mathrm{H} 2 \mathrm{O}-0.5 \mathrm{~g}, \mathrm{MgSO}_{4}$ $.7 \mathrm{H}_{2} \mathrm{O}-0.025 \mathrm{~g}$, KCl-0.02g and $\left(\mathrm{NH}_{4}\right)_{2} \mathrm{SO}_{4}{ }^{-}$ $0.01 \mathrm{~g}$, supplemented with $25 \%$ PEG 8000 to attain an osmotic potential of - 1.97 MPa was used. The un-supplemented NBRIP medium having an osmotic potential of $-0.97 \mathrm{MPa}$, was used as a control. One $\mathrm{ml}\left(10^{8} \mathrm{cfu} / \mathrm{ml}\right)$ each of the individual isolates was inoculated in NBRIP medium and incubated at $30^{\circ} \mathrm{C}$ for 7 days in shaking incubator at $60 \mathrm{rpm}$ After seven days incubation, the culture was centrifuged at $10000 \mathrm{rpm}$ for 10 minutes at room temperature and the supernatant was collected. After recording the $\mathrm{pH}$ of the supernatant, it was filtered through $0.25 \mu \mathrm{M}$ filters (Pall Bioscience, USA) and the organic acid profile was determined by HPLC. Quantification of organic acids was carried out as per as described by Hazer et al., (2016), with minor deviations using a HPLC (Model: Prominence, Shimadzu, Japan), equipped with photodiode array detector (SPD-M20A) and Synergi $4 \mu \mathrm{m}$ RP-C18 column (Phenomenex, USA, 250X4.6 mm). The organic acids were resolved using isocratic run of mobile phase consisted of $1 \mathrm{mM} \mathrm{H} \mathrm{SO}_{4}+8 \mathrm{mM} \mathrm{Na}_{2} \mathrm{SO}_{4}$ $(1: 1 \mathrm{v} / \mathrm{v})$ containing $0.1 \%$ ortho phosphoric acid at $0.5 \mathrm{ml} / \mathrm{min}$ flow rate. The organic acids were quantified at $210 \mathrm{~nm}$ by comparing the retention times and peak areas of standard 
organic acids viz., 2-ketoglutaric, oxalic, tartaric, formic, malic, malonic, lactic, citric, succinic and propionic acids purchased from Sigma Aldrich (USA). The quantitative estimation of phosphate released as a result of the microbial solubilization was measured in terms of the soluble $\mathrm{P}$ concentration of the culture supernatant by the method of Murphy and Riley (1962). All the experiments were performed in triplicates. The data generated from the experiment were analysed using SAS 9.3 version of the statistical package (SAS Institute Inc, 2011). Analysis of variance (ANOVA) was performed using SAS PROC ANOVA procedure. Means were separated using Fisher's protected least significant difference (LSD) test at a probability level of $\mathrm{p}<0.01$.

\section{Results and Discussion}

\section{Organic acid production profile}

The HPLC analysis of culture supernatants showed the presence nine organic acids viz., citric, formic, 2-keto glutaric acid, lactic, malic, malonic, propionic, succinic, and tartaric acids (Table 1). Irrespective of the organic acid there was a significant difference between isolates with reference to their levels of organic acid production. However, the effect of osmotic stress on organic acid production was non-significant across acids. Under osmotic stress conditions the isolate Bacillus sp. G-4 produced the highest levels of citric acid $(16.28 \mu \mathrm{g} / \mathrm{ml})$, lactic acid (50.62 $\mu \mathrm{g} / \mathrm{ml})$ and malic acid $(40.60 \mu \mathrm{g} / \mathrm{ml})$, while the isolate Enterobacter sp. P-39 produced the highest level of formic acid $(5.76 \mu \mathrm{g} / \mathrm{ml})$. The highest level of 2- keto glutaric acid (19.77 $\mu \mathrm{g} / \mathrm{ml}$ ) was produced under stress conditions by the isolate Enterobacter sp. P-68. The isolate Bacillus sp. CP-2 produced the highest level of malonic acid $(45.93 \mu \mathrm{g} / \mathrm{ml})$ while the highest levels of propionic acid $(0.7 \mu \mathrm{g} / \mathrm{ml})$, succinic acid $(6.23 \mu \mathrm{g} / \mathrm{ml})$ and tartaric acid
(23.2 $\mu \mathrm{g} / \mathrm{ml})$ were produced by the isolates Bacillus amyloliquefaciens P-72, Enterobacter sp. P-76 and Enterobacter P-41 respectively.

In the present study, the determination of organic acid production profile of twelve osmotolerant bacterial isolates by HPLC analysis of the culture supernatant revealed significant differences in the levels of different organic acids produced by individual isolates. But the effect of osmotic stress on the organic acid production by the isolates was nonsignificant across isolates. An interesting feature of this study is the lack of a direct correlation between the highest levels of $\mathrm{P}$ solubilization and highest levels of organic acid production. Bacillus amyloliquifaciens $\mathrm{P}-$ 72 that solubilised the highest levels of $\mathrm{P}$ was not a very significant producer of all organic acids with the exception of propionic acid. This could be attributed to other mechanisms of $\mathrm{P}$ solubilisation that operate in tandem apart from the cumulative organic acid production by the bacterium. This finding is supported by the earlier observation that though organic acid production by microorganisms is one of the major factors that influence phosphate solubilization, it is not the sole factor that determines phosphate solubilisation (Chen et al., 2005).

\section{Phosphate solubilization}

In this study, PEG 8000 was used to induce osmotic stress in the culture medium, but all isolates were able to grow and solubilise phosphates in the medium which was evident by the reduction in the $\mathrm{pH}$ of the medium and the detection of soluble forms of phosphorus in the culture supernatant. Under non-osmotic conditions, the soluble $\mathrm{P}$ levels recorded by the isolates ranged from 2.78-25.22 ppm whereas under osmotic stress conditions it ranged from 4.67-53.56 ppm. Amongst the osmotolerant bacterial cultures, the isolate Bacillus amyloliquefaciens P-72 recorded 
significantly higher soluble $\mathrm{P}$ concentrations (53.56 ppm) under osmotic stress conditions while the isolate Enterobacter sp. P-39 recorded the lowest soluble $\mathrm{P}$ concentration (4.98 ppm). Most isolates were able to solubilize tricalcium phosphate more efficiently under osmotic stress conditions than under normal conditions (Figure 1).

Phosphate solubilizing bacteria are known to improve solubilization of fixed soil phosphorus and applied phosphates, resulting in higher crop yields (Yadav and Dadarwal, 1997). Such species solubilize insoluble $P$ forms by processes that include organic acid production, chelation and ion exchange reactions, thereby making the soluble forms freely available to plants (Vessey, 2003). But the $\mathrm{P}$ solubilizing activity is majorly attributed to the microbial ability to produce and release organic acids, which through their carboxylic groups chelate the cations (mainly $\mathrm{Ca}$ ), bound to phosphates thereby converting them into the soluble forms (Kpombleklou and Tabatabai, 1994). The production of organic acids results in acidification of the microbial cell and its surroundings by decreasing the $\mathrm{pH}$. The amount and type of the organic acid produced vary with the microorganism. The amount of soluble phosphate released depends on the strength and type of acid (Chandandeep et al., 2016). Various P-solubilizing species of Bacillus viz., B. licheniformis, $B$. amyloliquefaciens, B. firmus etc., are known to produce a mixture of lactic, oxalic, glycolic, 2-ketoglutaric acid, malonic, and succinic acid (Rodriguez and Fraga, 1999).

Fig.1 Effect of osmotic stress on phosphate solubilization by osmotolerant bacterial isolates

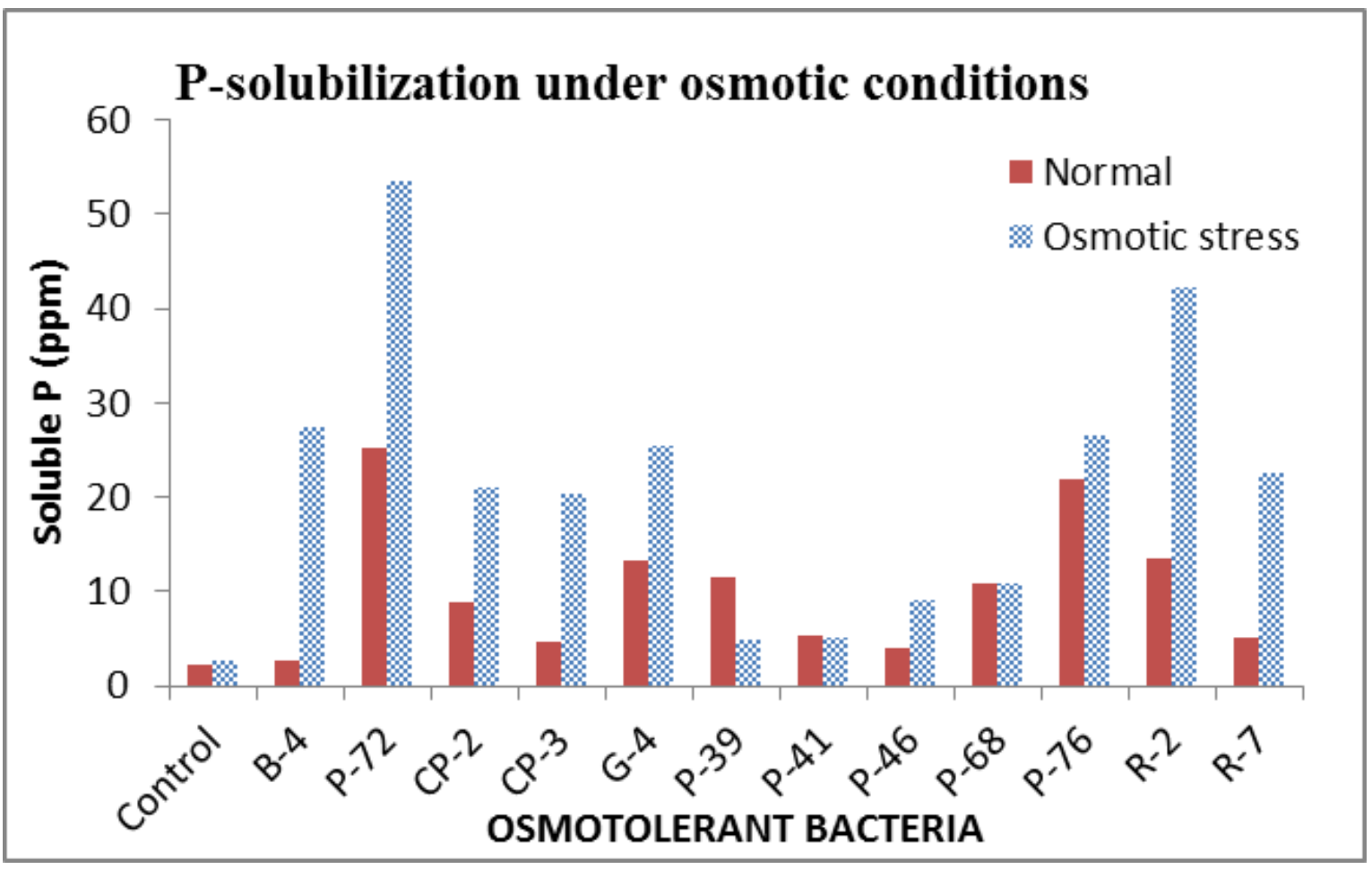


Table.1 Effect of osmotic stress on the organic acid profile of osmototolarant bacteria

\begin{tabular}{|c|c|c|c|c|c|c|c|c|c|c|c|c|c|c|c|c|c|c|}
\hline \multirow{3}{*}{$\begin{array}{l}\text { Bacterial } \\
\text { strains }\end{array}$} & \multicolumn{18}{|c|}{ Organic acid $(\mu \mathrm{g} / \mathrm{ml})$} \\
\hline & \multicolumn{2}{|c|}{ Citric acid } & \multicolumn{2}{|c|}{ Formic acid } & \multicolumn{2}{|c|}{$\begin{array}{l}\text { 2-Keto glutaric } \\
\text { acid }\end{array}$} & \multicolumn{2}{|c|}{ Lactic acid } & \multicolumn{2}{|c|}{ Malic acid } & \multicolumn{2}{|c|}{ Malonic acid } & \multicolumn{2}{|c|}{ Propionic acid } & \multicolumn{2}{|c|}{ Succinic acid } & \multicolumn{2}{|c|}{ Tartaric acid } \\
\hline & $\mathbf{S}$ & $\mathbf{N}$ & $\mathbf{S}$ & $\mathbf{N}$ & $\mathbf{S}$ & $\mathbf{N}$ & $\mathbf{S}$ & $\mathbf{N}$ & $\mathbf{S}$ & $\mathbf{N}$ & $\mathbf{S}$ & $\mathbf{N}$ & $\mathbf{S}$ & $\mathbf{N}$ & $\mathbf{S}$ & $\mathbf{N}$ & $\mathbf{S}$ & $\mathbf{N}$ \\
\hline B-4 & $4.37^{\mathrm{E}}$ & $3.40^{\mathrm{DE}}$ & $3.56^{\mathrm{B}}$ & $3.14^{\mathrm{E}}$ & $4.16^{\mathrm{G}}$ & $2.88^{\mathrm{HI}}$ & $9.05^{\mathrm{G}}$ & $11.10^{\mathrm{H}}$ & $28.13^{\mathrm{C}}$ & $20.90^{\mathrm{D}}$ & $41.17^{\mathrm{B}}$ & $35.49^{\mathrm{A}}$ & $0.53^{\mathrm{ABC}}$ & $0.56^{\mathrm{C}}$ & $2.12^{\mathrm{D}}$ & $2.34^{\mathrm{C}}$ & $4.26^{\mathrm{H}}$ & $5.48^{\mathrm{G}}$ \\
\hline $\mathrm{CP} 2$ & $4.17^{\mathrm{E}}$ & $2.08^{\mathrm{F}}$ & $3.66^{\mathrm{B}}$ & $3.87^{\mathrm{D}}$ & $16.90^{\mathrm{B}}$ & $9.85^{\mathrm{C}}$ & $23.02^{\mathrm{C}}$ & $18.06^{\mathrm{F}}$ & $20.11^{\mathrm{EF}}$ & $23.68^{\mathrm{B}}$ & $45.93^{A}$ & $37.05^{\mathrm{A}}$ & $0.45^{\mathrm{BCD}}$ & $0.56^{\mathrm{C}}$ & $1.05^{\mathrm{E}}$ & $1.89^{\mathrm{D}}$ & $16.07^{\mathrm{B}}$ & $15.65^{\mathrm{B}}$ \\
\hline $\mathrm{CP} 3$ & $7.15^{\mathrm{C}}$ & $4.05^{\mathrm{D}}$ & $1.94^{\mathrm{CD}}$ & $2.93^{\mathrm{F}}$ & $6.78^{\mathrm{F}}$ & $4.33^{\mathrm{F}}$ & $22.69^{C}$ & $30.93^{\mathrm{C}}$ & $26.37^{\mathrm{D}}$ & $23.23^{\mathrm{B}}$ & $25.57^{\mathrm{G}}$ & $27.40^{\mathrm{B}}$ & $0.33^{\mathrm{CD}}$ & $0.26^{\mathrm{F}}$ & $2.03^{\mathrm{D}}$ & $2.78^{\mathrm{B}}$ & $4.92^{\mathrm{G}}$ & $6.68^{\mathrm{E}}$ \\
\hline G-4 & $16.28^{A}$ & $14.84^{\mathrm{A}}$ & $0.86^{\mathrm{DE}}$ & $1.09^{I}$ & $19.29^{\mathrm{A}}$ & $13.34^{\mathrm{A}}$ & $50.62^{\mathrm{A}}$ & $39.83^{\mathrm{B}}$ & $40.60^{A}$ & $31.50^{A}$ & $37.22^{\mathrm{C}}$ & $33.41^{\mathrm{A}}$ & $0.51^{\mathrm{BC}}$ & $0.52^{\mathrm{CD}}$ & $3.58^{\mathrm{B}}$ & $5.85^{\mathrm{A}}$ & $5.09^{\mathrm{G}}$ & $4.79^{\mathrm{H}}$ \\
\hline P-39 & $3.58^{\mathrm{F}}$ & $3.44^{\mathrm{DE}}$ & $5.76^{\mathrm{A}}$ & $7.85^{A}$ & $3.25^{\mathrm{H}}$ & $2.36^{\mathrm{I}}$ & $12.16^{\mathrm{F}}$ & $16.43^{\mathrm{G}}$ & $19.37^{\mathrm{FG}}$ & $15.72^{\mathrm{G}}$ & $22.70^{\mathrm{H}}$ & $19.15^{\mathrm{DE}}$ & $0.23^{\mathrm{DE}}$ & $0.12^{\mathrm{G}}$ & $1.03^{\mathrm{E}}$ & $1.14^{\mathrm{EF}}$ & $13.30^{\mathrm{C}}$ & $10.29^{C}$ \\
\hline P-41 & $4.00^{\mathrm{EF}}$ & $3.31^{\mathrm{E}}$ & $7.03^{\mathrm{A}}$ & $6.26^{\mathrm{B}}$ & $8.63^{\mathrm{E}}$ & $6.77^{\mathrm{E}}$ & $20.05^{\mathrm{D}}$ & $28.31^{\mathrm{D}}$ & $11.70^{\mathrm{H}}$ & $12.65^{\mathrm{H}}$ & $29.52^{\mathrm{F}}$ & $21.06^{\mathrm{CD}}$ & $0.25^{\mathrm{DE}}$ & $0.08^{\mathrm{GH}}$ & $0.92^{\mathrm{EFG}}$ & $0.96^{\mathrm{FG}}$ & $23.27^{A}$ & $19.75^{A}$ \\
\hline P-46 & $10.58^{\mathrm{B}}$ & $8.06^{\mathrm{B}}$ & $2.06^{\mathrm{CD}}$ & $2.95^{\mathrm{F}}$ & $13.45^{\mathrm{C}}$ & $10.58^{\mathrm{B}}$ & $11.40^{\mathrm{F}}$ & $17.59^{\mathrm{FG}}$ & $19.56^{\mathrm{FG}}$ & $17.33^{\mathrm{F}}$ & $31.23^{\mathrm{E}}$ & $23.60^{\mathrm{BC}}$ & $0.56^{\mathrm{AB}}$ & $0.43^{\mathrm{E}}$ & $0.99^{\mathrm{EF}}$ & $1.25^{\mathrm{E}}$ & $5.04^{\mathrm{G}}$ & $6.37^{\mathrm{E}}$ \\
\hline P-68 & $5.53^{\mathrm{D}}$ & $3.61^{\mathrm{DE}}$ & $3.12^{\mathrm{BC}}$ & $4.42^{\mathrm{C}}$ & $19.77^{\mathrm{A}}$ & $13.18^{A}$ & $17.30^{\mathrm{E}}$ & $22.93^{\mathrm{E}}$ & $21.46^{\mathrm{E}}$ & $18.96^{\mathrm{E}}$ & $16.65^{\mathrm{I}}$ & $12.48^{\mathrm{F}}$ & $0.33^{\mathrm{CD}}$ & $0.22^{\mathrm{F}}$ & $0.77^{\mathrm{G}}$ & $0.73^{\mathrm{H}}$ & $9.00^{\mathrm{D}}$ & $8.73^{\mathrm{D}}$ \\
\hline P-72 & $1.06^{\mathrm{G}}$ & $1.03^{\mathrm{G}}$ & $3.61^{\mathrm{B}}$ & $2.66^{\mathrm{H}}$ & $4.05^{\mathrm{G}}$ & $3.67^{\mathrm{G}}$ & $7.23^{\mathrm{H}}$ & $9.21^{\mathrm{I}}$ & $18.50^{\mathrm{G}}$ & $10.47^{1}$ & $33.38^{\mathrm{D}}$ & $25.40^{\mathrm{B}}$ & $0.75^{A}$ & $0.92^{\mathrm{A}}$ & $0.49^{\mathrm{H}}$ & $0.73^{\mathrm{H}}$ & $9.04^{\mathrm{D}}$ & $8.62^{\mathrm{D}}$ \\
\hline P-76 & $7.00^{\mathrm{C}}$ & $5.46^{\mathrm{C}}$ & $1.32^{\mathrm{DE}}$ & $2.88^{\mathrm{G}}$ & $10.75^{\mathrm{D}}$ & $7.66^{\mathrm{D}}$ & $8.00^{\mathrm{H}}$ & $10.65^{\mathrm{H}}$ & $29.55^{\mathrm{B}}$ & $21.10^{\mathrm{D}}$ & $23.49^{\mathrm{H}}$ & $15.03^{\mathrm{EF}}$ & $0.27^{\mathrm{D}}$ & $0.74^{\mathrm{B}}$ & $6.23^{A}$ & $0.80^{\mathrm{GH}}$ & $6.21^{\mathrm{F}}$ & $5.23^{\mathrm{G}}$ \\
\hline $\mathrm{R} 2$ & $5.23^{\mathrm{D}}$ & $3.85^{\mathrm{DE}}$ & $3.33^{\mathrm{B}}$ & $2.56^{\mathrm{H}}$ & $8.12^{\mathrm{E}}$ & $6.55^{\mathrm{E}}$ & $11.35^{\mathrm{F}}$ & $9.45^{\mathrm{i}}$ & $26.56^{\mathrm{E}}$ & $23.22^{B}$ & $31.33^{\mathrm{E}}$ & $23.54^{\mathrm{B}}$ & $0.55^{A}$ & $0.42^{\mathrm{D}}$ & $0.98^{\mathrm{E}}$ & $0.73^{\mathrm{H}}$ & $9.01^{\mathrm{D}}$ & $8.55^{\mathrm{D}}$ \\
\hline $\mathrm{R} 7$ & $6.66^{\mathrm{C}}$ & $4.10^{\mathrm{D}}$ & $1.23^{\mathrm{DE}}$ & $1.03^{\mathrm{J}}$ & $6.74^{\mathrm{F}}$ & $4.32^{\mathrm{F}}$ & $34.34^{\mathrm{B}}$ & $42.46^{A}$ & $29.67^{\mathrm{B}}$ & $22.17^{\mathrm{C}}$ & $40.36^{\mathrm{B}}$ & $36.72^{\mathrm{A}}$ & $0.36^{\mathrm{BCD}}$ & $0.47^{\mathrm{DE}}$ & $2.44^{\mathrm{C}}$ & $2.85^{\mathrm{B}}$ & $7.03^{E}$ & $6.02^{\mathrm{F}}$ \\
\hline Control & $0.00^{\mathrm{H}}$ & $2.06^{\mathrm{F}}$ & $0.00^{\mathrm{E}}$ & $0.00^{\mathrm{K}}$ & $0.52^{\mathrm{I}}$ & $3.04^{\mathrm{H}}$ & $0.00^{1}$ & $2.40^{\mathrm{J}}$ & $1.07^{\mathrm{I}}$ & $0.00^{\mathrm{J}}$ & $0.00^{\mathrm{J}}$ & $0.71^{\mathrm{G}}$ & $0.03^{\mathrm{E}}$ & $0.06^{\mathrm{H}}$ & $0.82^{\mathrm{FG}}$ & $0.00^{I}$ & $0.02^{1}$ & $0.04^{1}$ \\
\hline LSD@1\% & 0.568 & 0.702 & 1.424 & 0.047 & 0.609 & 0.623 & 0.838 & 1.353 & 1.374 & 0.546 & 1.456 & 4.127 & 0.222 & 0.0615 & 0.1985 & 0.2256 & 0.5715 & 0.323 \\
\hline Culture & \multicolumn{2}{|c|}{$* *$} & \multicolumn{2}{|c|}{$* *$} & \multicolumn{2}{|c|}{$* *$} & \multicolumn{2}{|c|}{$* *$} & \multicolumn{2}{|c|}{$* *$} & \multicolumn{2}{|c|}{$* *$} & \multicolumn{2}{|c|}{$* *$} & \multicolumn{2}{|c|}{ NS } & \multicolumn{2}{|c|}{$* *$} \\
\hline Condition & \multicolumn{2}{|c|}{ NS } & \multicolumn{2}{|c|}{ NS } & \multicolumn{2}{|c|}{ NS } & \multicolumn{2}{|c|}{ NS } & \multicolumn{2}{|c|}{ NS } & \multicolumn{2}{|c|}{ NS } & \multicolumn{2}{|c|}{ NS } & \multicolumn{2}{|c|}{ NS } & \multicolumn{2}{|c|}{ NS } \\
\hline $\begin{array}{l}\text { Culture* } \\
\text { Condition }\end{array}$ & \multicolumn{2}{|c|}{$*$} & * & & $*$ & $*$ & $*$ & $*$ & $*$ & & & $*$ & 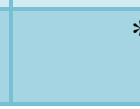 & $*$ & $* *$ & $*$ & & * \\
\hline
\end{tabular}


The utilization of osmotolerant bacteria as bioinoculants open up an exciting possibility for alleviation of deficit water stress effects in various crops and growing situations. Enhancement of rhizospheric phosphorus availability plays a major role in the alleviation of deficit water stress effects since phosphorus availability has a direct correlation with the root development and water/ nutrient uptake. In such a scenario, it is imperative to understand the effects of osmotic stress on the organic production profiles and phosphate solubilization capacities of the organisms selected for the purpose.

The present study is unique since it has determined the effects of osmotic stress on the organic acid profiles and phosphate solubilization abilities of osmotolerant bacterial isolates. Though earlier reports on the ability of Pseudomonas and Bacillus species to solubilize the inorganic mineral phosphates under osmotic stress conditions, and their overall effect on growth of sorghum, sunflower and maize plants under water stressed conditions are available (Sandhya et al., 2009), the effect of osmotic stress on the organic acid profile of osmotolerant bacterial isolates has not been studied so earlier.

In conclusion, this study revealed that under osmotically stressed situations, osmotolerant bacteria have a differential organic acid production profile and are better adapted for phosphate solubilisation. The utilization of such isolates that are not impaired in their phosphate solubilization abilities as a result of osmotic stress can be an effective tool for enhancing crop productivity in water stressed environments.

\section{Acknowledgement}

This work was supported by the Indian Council of Agricultural Research, New Delhi under the National Innovations on Climate Resilient Agriculture (NICRA) project.

\section{Conflicts}

The authors declare that there exist no conflicts of interest.

\section{References}

Bhattacharyya, P., and Jain R K. 2000. Phosphorus solubilising biofertilisers in the whirlpool of rock phosphatechallenges and opportunities. Fertiliser News. 10: 45-52

Chandandeep, K., G. Selvakumar and Ganeshamurthy, A.N. 2016. Organic acids in the rhizosphere: their role in phosphate dissolution. In: Microbial inoculants in sustainable agricultural productivity (Eds.) D.P. Singh. Springer, India. Pp. 165-177.

Chen, X., J. Tang, G. Zhi and Hu, S. 2005. Arbuscular mycorrhizal colonization and phosphorus acquisition of plants: effects of coexisting plant species. Appl Soil Ecol. 28: 259-269.

Duponnois, R., A. Colombet, V. Hien and Thioulouse, J. 2005. The mycorrhizal fungus Glomus intraradices and rock phosphate amendment influence plant growth and microbial activity in the rhizosphere of Acacia holosericea. Soil Biol Biochem. 37: 1460-1468

Hazer, O., M. Akkbik and Gungor, K. 2016. Simultaneous determination of the main organic acids in Anatolian black pine by HPLC with DAD Detector. Eurasian J Anal Chem. 11: 181-195.

Illmer, P., and Schinner, F. 1992. Solubilization of inorganic phosphates by microorganisms isolated from forest soils. Soil Biol Biochem. 24: 389-395.

Kpomblekou, K., and Tabatabai, M.A. 1994. Effect of organic acids on release of phosphorus from phosphate rocks. Soil 
Sci. 158: 442-453.

Kucey, R.M.N. 1983. Phosphate-solubilizing bacteria and fungi in various cultivated and virgin Alberta soils. Can J Soil Sci. 63: 671-678.

Murphy, J., and Riley, J.P. 1962. A modified single solution method for the determination of phosphate in natural waters. Anal Chim Acta. 27: 31-36

Narula, N., V. Kumar, R.K. Behl and Duebel A.A. 2000. Effect of $\mathrm{P}$ solubilising Azotobacter chroococcum on N, P, K uptake in $\mathrm{P}$ responsive wheat genotypes grown under greenhouse conditions. J Plant Nutr Soil Sci. 163: 393-398.

Omar, S.A. 1998. The role of rock-phosphatesolubilizing fungi and vesicular arbuscular-mycorrhiza (VAM) in growth of wheat plants fertilized with rock phosphate. World $\mathrm{J}$ Microbiol Biotechnol. 14: 211-218.

Rodriguez, H., and Fraga, R. 1999. Phosphate solubilizing bacteria and their role in plant growth promotion. Biotechnol Adv. 17: 319-339.

Sandhya, V., S.K.Z. Ali, G. Minakshi and Reddy G. 2009. Alleviation of drought stress effects in sunflower seedlings by the exopolysaccharides producing Pseudomonas putida strain
GAP-P45. Biol Fert Soils. 46: 17-26.

Selvakumar, G., P. Joshi, P. Suyal, P.K. Mishra and Joshi, G.K. 2013. Rock phosphate solubilization by psychrotolerant Pseudomonas species and their effect on lentil growth and nutrient uptake under polyhouse conditions. Ann Microbiol. 63: 13531362.

Vazquez, P., G. Holguin, M.E. Puente, A. Lopez Cortes and Bashan, Y. 2000. Phosphate solubilising microorganisms associated with the rhizosphere of mangroves in a semi-arid coastal lagoon. Biol Fert Soils. 30: 460-468.

Vessey, J. K. 2003. Plant growth promoting rhizobacteria as bio fertilizers. Plant Soil. 255: 571-586.

Whitelaw, M.A. 2000. Growth promotion of plants inoculated with phosphate solubilising fungi. Adv Agron. 69: 99151.

Yadav, K. S., and Dadarwal, K.R. 1997. Phosphate solubilization and mobilization through soil microorganisms. In: Biotechnological Approaches in Soil Microorganisms for Sustainable Crop Production (Eds.) Dadarwal R. K., Scientific Publishers, Jodhpur. India. Pp. 293-308.

\section{How to cite this article:}

Gurupadam Hema Bindu, Govindan Selvakumar, Kaushal K. Upreti, Narayana Sunil Kumar and Duraisamy Kalaivanan. 2018. Effect of Osmotic Stress on the Organic Acid Production Profile and Tricalcium Phosphate Solubilization by Osmotolerant Bacteria. Int.J.Curr.Microbiol.App.Sci. 7(12): 1177-1183. doi: https://doi.org/10.20546/ijcmas.2018.712.146 